\title{
Chinese Women Experience a Negative Side EFFeCt of the GROWING PRIVATE SECTOR IN GENDER-BASED EMPLOYMENT DISCRIMINATION
}

\section{INTRODUCTION}

Discrimination against women occurs throughout the world, in all areas of life. Violations persist against women's rights despite condemnation by the international community in addition to individual countries. The women of the People's Republic of China (hereinafter China) face great discrimination as a result of the cultural traditions and values of the Chinese, which in large part are based on Confucian teachings. Mao Zedong attempted to eliminate the stratification between the sexes by placing extreme restrictions on the personal rights of all citizens. ${ }^{1}$ Recently, the inherent biases against women in China have re-emerged, especially in the work force, due to the surge of the market economy. ${ }^{2}$

The Chinese government is loosening its traditionally tight grip on the economy, intending to allow the development of a market economy. Lifting some of the numerous regulations restricting private businesses allows employers more freedom to act on their biases and prejudices, resulting in an increase in gender-based employment discrimination in China.

China does have extensive laws and provisions prohibiting discrimination against women, but they are not effectively enforced. The laws prohibit discrimination, mandate equal remuneration, and include protective measures for women. Despite the laws, gender-based discrimination in China's work force continues virtually unchecked.

The United States and the United Nations have repeatedly condemned China's discrimination against women, as well as China's other human rights violations, which are beyond the scope of this comment. The Chinese government claims that it attempts to minimize its violations against women's rights. ${ }^{3}$ Some sources even point to foreign-invested joint ventures as the primary violators of Chinese labor laws, ${ }^{4}$ which include anti-discrimination provisions. At the same time that foreigners are being blamed, the Chinese government discourages efforts by outside forces attempting to improve human rights practices.

1. James C. Hsiung, human Rights in EAst Asia: A Cultural Perspective 122 (1985).

2. Leah Makabenta, China: Economic Progress Makes Life Harder for Women, INTER PRESS SERVICE, Oct. 7, 1992 available in LEXIS, ASIAPC Library, INPRES File.

3. James Lilley, Address at the Women's Nat'l Democratic Club (May 31, 1994), available in LEXIS, ASIAPC Library, FEDNEW File.

4. China: Joint Ventures Must Set Up Trade Unions, ChINA DALlY, Aug. 25, 1994. 
The United States does have the means to bring about improvement in the treatment of women in the Chinese work force by pressuring the government through various trade restrictions. American companies could be encouraged, or required, to adopt a code of conduct whereby they could monitor their own human right's practices when dealing with China. Some American companies have already responded to the human rights violations in China by placing voluntary restrictions on business conducted there. ${ }^{3}$ Action by outside sources would serve to notify the Chinese government of the concerns of the international community, improve the treatment of those Chinese employees directly affected, and influence other businesses and companies to join the United States in the fight for the equal treatment of Chinese women.

Although biases need to be addressed and eliminated from within each person individually, the increase in gender-based discrimination cannot be tolerated. The increase in discrimination within the work force needs to be brought under control and prevented from growing along with the economy. If the Chinese government is not enforcing the anti-discrimination laws already in place, the United States can lead the way in addressing the issue and equalizing the opportunities available to both sexes. Developing equality in the work force will reflect in other areas of women's lives, contributing to the benefit and well-being of the country and the people as a whole.

This Comment addresses the increase in gender-based employment discrimination in China as a result of the changing dynamics of the country and the role and responsibilities of the international community in furthering equality among the sexes. Part II looks at the international provisions promoting the rights of women, while part III introduces and evaluates China's own regulations which deal with gender based discrimination. Parts IV and $V$ then discuss the pervasiveness of female oppression, while also looking at the contributing historical, cultural, and political factors. These sections focus on the labor market and how women are being limited in this particular aspect of society. Finally, part VI explores how the international market has effected China's human rights record and what the United States and other foreign investors in China can do to help improve the plight of Chinese women until gender equality is fully recognized and actualized.

\section{The International Prohibition Against Gender-Based DISCRIMINATION AND THE POSITION OF THE UNITED NATIONS}

\section{A. The Charter of the United Nations}

The right of women to be free from discrimination is a fundamental and well established universal right. The Charter of the United Nations 
clearly addressees and condemns gender based discrimination at two separate places within its original charter. Article I, section 3 declares that "to achieve international cooperation in solving international problems of an economic, social, cultural, or humanitarian character, and in promoting and encouraging respect of human rights and for fundamental freedoms for all" there must be equality "without distinction as to race, sex, language, or religion." This general statement of purpose is followed by the second and more specific call of Article 55:

With a view to the creation of conditions of stability and well-being which are necessary for peaceful and friendly relations among nations based on respect for the principle of equal rights and self-determination of peoples, the United Nations shall promote ... universal respect for, and observance of, human rights and fundamental freedoms for all without distinction as to race, sex, language, or religion.?

The inclusion of women's rights in the Charter of the United Nations was re-emphasized at the 1993 World Conference on Human Rights. ${ }^{8}$ The conference adopted action requiring a systematic integration of women's issues into the United Nation's human rights programs. ${ }^{9}$

\section{B. The United Nations Convention on the Elimination of All Forms of Discrimination Against Women}

In the continuing effort by the United Nations to further its fundamental principle of eliminating gender-based discrimination, the Convention on the Elimination of All Forms of Discrimination Against Women was opened for signature in March of $1980 .^{10}$ Many reasons are given within the U.N. Women's Convention for the necessity of its ratification including:

discrimination against women violates the principles of equality of rights and respect for human dignity, is an obstacle to the participation of women, on equal terms with men, in the political, social, economic and cultural life of their counties, hampers the growth of the prosperity of society and the family and makes more difficult the full development of the potentiali-

6. U.N. CHARTER art. 1.

7. U.N. CHARTER art. 55.

8. Violations of Women's Human Rights, DEP'T. OF ST. DISPATCH (U.S. DEP'T OF ST.), Oct. 11, 1993.

9. Id.

10. Convention on the Elimination of All Forms of Discrimination Against Women, opened for signature Mar. 1, 1980, 19 I.L.M. 33 [hereinafter U.N. Women's Convention]. 
ties of women in the service of their countries and of humanity ... the full and complete development of a country, the welfare of the world and the cause of peace require the maximum participation of women on equal terms with men in all fields. ${ }^{11}$

Although discrimination is condemned within the U.N. Charter, as well as in the Universal Declaration of Human Rights ${ }^{12}$ and the International Covenant on Economic, Social and Cultural Rights, ${ }^{13}$ it is noted within the U.N. Women's Convention that gender-based discrimination continues and must be addressed further. ${ }^{14}$

Members of the U.N. Women's Convention, including China, are requested to embody gender equality within their constitution, and to enact any other legislation necessary to reach the desired end of equality. ${ }^{15}$ Article 11 of the U.N. Women's Convention is the section that directly addresses discrimination in the field of employment, and specifically addresses equal opportunity, equal remuneration, safety, and extensive protection against discrimination on the grounds of marriage and maternity. ${ }^{16}$ In name, China has met the requirements of the U.N. Women's Conventions on these issues by enacting legislation declaring equality and maternity protection, and by including the anti-discrimination provisions in the constitution. ${ }^{17}$ But China has not yet actually been able to realize equality between the genders in the labor market, which is the ultimate goal.

Discrimination against women is defined in Article 1 of the U.N. Women's Convention as "any distinction, exclusion or restriction made on the basis of sex."18 Temporary special measures to encourage equality are acceptable under the U.N. Women's Convention as long as they do not

11. Id. at 35 .

12. The Universal Declaration of Human Rights was proclaimed by the general assembly on December 10,1948, and is the "common standard for achievement for all peoples and all nations." This entitles all people to a set of freedoms, and prohibits distinction of sex in the application of the freedoms. WINSTON E. LANGLEY, WOMEN's RTS. IN INT'L. DOCUMENTS 7 (1991).

13. The U.N.'s International Covenant on Economic, Social, and Cultural Rights guarantees women equal remuneration with men for work of equal value as well as equal opportunities for employment. Id. at 10.

14. U.N. Women's Convention, supra note 10.

15. Id.

16. Id. The United States is not a member of this convention because of the requirement of paid maternity leave. "What is good in the conventions is already protected by U.S. law." The United States may declare reservations, limiting the United States required compliance. Panelist at Senate Foreign Relations Hearing Address Concerns about U.N. Women's Convention, INT'L. BuS. \& FIN. DAILY, Sept. 29, 1994.

17. See infra part IIl.

18. U.N. Women's Convention, supra note 10. 
result in unequal or separate standards. ${ }^{19}$ It also makes clear that the measures protecting maternity leave and pregnancy are not considered discriminatory and are greatly encouraged. ${ }^{20}$ The Chinese have many laws concerning women. ${ }^{21}$ Most of China's laws purely promote equality, but several of the provisions are considered laws of protection and make clear distinctions between the sexes. Most of the protective laws center around pregnancy and maternity leave, which comply with the provisions of the U.N. Women's Convention.

\section{The International Labor Organization}

Another arm of the United Nations, the International Labor Organization (ILO), addresses women's rights of freedom from discrimination in the work force from the labor angle. The ILO sets out three fundamental human rights as follows: 1) freedom of association; 2) freedom from forced labor; and 3) equality of opportunity and treatment, including freedom from discrimination. ${ }^{22}$ The preamble of the ILO's Constitution makes specific provisions for the protection of women and the requirement of equal pay for equal work. ${ }^{23}$ Gender-based employment discrimination falls squarely within the concerns of the ILO. The ILO allows, and even requires, whatever resources possible to eliminate the problem. The United Nations and the United States have clearly placed the Chinese on notice that the rights of women are of international concern and needs to be successfully addressed by the Chinese government. China has a number of provisions prohibiting discrimination against women, but the effectiveness of these laws is questionable.

\section{ChINA's ANTI-DisCRIMINATION PROVISIONS}

\section{A. The Constitution of the People's Republic of China}

China has extremely firm laws prohibiting any type of discrimination against women. These provisions are found at multiple levels, from the constitution to local regulations. Discrimination against women is explicitly prohibited within Article 48 of the Chinese Constitution (Constitution). Women in The People's Republic of China enjoy equal rights with men in all spheres of life; political, economic, cultural and social, including family life.

19. Id. art. 4.

20. Id.

21. See infra part III.

22. Karen F. Travis, Women in Global Production and Worker Rights Provisions in U.S. Trade Laws, 17 YALE J. INT'L L. 173 (1992).

23. Int'l. Lab. Organization Const. Pmbl., T.I.A.S. No. 1868. 
The state protects the rights and interests of women, applies the principle of equal pay for equal work for men and women alike and trains and selects cadres from among women. ${ }^{24}$ This constitutional grant of equality is powerfully stated. Women are to be considered and treated as equals in all areas of life, including the work place. The fact that equality is assured within the constitution suggests China's compliance with the mandates of the United Nations. ${ }^{25}$

\section{B. Rules on the Labor Protection of Female Workers}

One of the first laws created specifically for the benefit of women, which has now been repealed, was the "Rules on the Labor Protection of Female Workers" (1988 Rules) ${ }^{26}$ Although the law declared the equality of women, it also included many protective provisions, including those assuring paid maternity leave and prohibiting the dismissal of women due to pregnancy or age. ${ }^{27}$ The 1988 Rules then set out numerous prohibitions intended to protect women, including one preventing women from working in mines. ${ }^{28}$ Article 6 restricted women by stating: "No unit may assign any female worker, during her menstruation, to work in high altitude, under low temperature, or in cold water, or to perform manual labor that requires grade three stamina stipulated by the state." ${ }^{29}$ There were even more provisions describing what pregnant or nursing women can and cannot do. $^{30}$ These types of protective provisions included in the 1988 Rules distinguish women from men and perpetuate discrimination.

The provisions in the 1988 Rules serve as an example of the Chinese perception of women and their abilities, versus the ability of men. Although the current laws focus more on equal rights than on special rights, the distinctions are still evident in several of the provisions. The Constitution is the only source of women's rights which purely emphasizes complete equality of the sexes. ${ }^{31}$

\section{The Law Protecting Women's Rights and Interests}

China re-emphasized its commitment to gender equality by passing the "Law Protecting Women's Rights and Interests" (1992 Law) on April 3,

24. XIANFA art. 48 [hereinafter ChINA ConST.].

25. See supra part II.A.

26. Rules on the Labor Protection of Female Workers, adopted June 28, 1988, in Statutes and Reg. OF THE PEOPle's Republic of China (1989).

27. Id. art. 4 , art. 8.

28. Id. art. 5.

29. Id. art. 6.

30. See also infra text accompanying note 97 (discussing biological differences as primary source of discrimination).

31. See supra part III.A. 
1992. 32 This law states that one of its purposes is to "enable women to play an active role in socialist modernization." 33 It then repeats what is stated in the Constitution: "Women enjoy the same rights as men in political, economic, cultural, social, and family life. . . . Discrimination against, abusing, or injuring women is prohibited." 34 Chapter IV of this law is entitled "Right To Work" and contains seven articles stating that there can be no discrimination in hiring, pay, or firing. ${ }^{39}$

The 1992 Law explicitly provides women equal rights with men in all areas of life. The law also goes one step further than the Constitution by including special protection for women during pregnancy and maternity leave. ${ }^{36}$ The protective measures found in the 1992 Law are not as extensive as those discussed in the 1988 Rules. ${ }^{37}$ The type of protective measures for women found in the 1992 Law are considered acceptable types of differentiation between the sexes by the U.N. Women's Convention. ${ }^{38}$ One final part of the 1992 Law to note is Chapter VIII, Legal Responsibility, providing women with remedies against businesses which violate the law. The remedies range from initiating legal proceedings, to turning to concerned departments or organizations for assistance. ${ }^{39}$ Despite the given remedies, the law is criticized for having no mechanism for enforcement, and therefore only being useful as an educational tool. ${ }^{40}$

\section{Local Legislation Furthering the Promotion of Women's Rights}

Even after the 1992 Law was enacted, some municipalities created their own local labor laws to promote the equality of women. The Local People's Congress of Tianjin adopted detailed regulations for the protection of women's rights and interests on September 7, 1994. ${ }^{41}$ This local law contains provisions which prohibit establishments, including businesses and schools, "from discriminating against women in signing working contracts." 42 It also provides that "women cannot be forced to leave their

32. Law Protecting Women's Rights and Interests, DAILY REPORT: CHINA, Apr. 14, 1992, at 17.

33. Id.

34. Id.

35. Id. at 18. But cf. supra part III.B. (special protection provisions contained within the law occasionally go too far).

36. Law Protecting Women's Rights and Interests, supra note 32, at 25.

37. See supra part III.B.

38. See supra part II.B. para. 3.

39. Law Protecting Women's Rights and Interests, supra note 32, at 20.

40. Sheryl WuDunn, Profit and Loss: China's Affection for Capitalism Erodes Gains in Equal Rights, CHI. TRIB., Sept. 27, 1992, at 5.

41. Tianjin Formulates Local Regulations to Protect Women's Rights, XINHUA NEWS AGENCY, Sept. 18, 1994, available in LEXIS, ASIAPC Library, XINHUA File.

42. China's Women Secure More Legal Protection, UPI, Sept. 20, 1994, available in LEXIS, ASIAPC Library, UPI File. 
posts before they reach the retirement age set by the government, sixty, and cannot be dismissed because they are married, pregnant or breast feeding." 43 This law is similar to the Law Protecting Women's Rights and Interests in that it includes protective provisions along with the declaration of equality.

The above laws protecting women's rights suggest that China is devoted to this cause and is exercising every effort to realize the desired equality. However, the repetitive laws declaring the equality of women are apparently insufficient to reach the desired goals in that "[f]undamental human rights provided for in the Constitution are frequently ignored in practice." ${ }^{44}$ Because of the strong language of the Chinese Constitution, declaring equality with men "in all spheres of life" and "equal pay for equal work for men and women alike," under the Constitution. The $1992 \mathrm{Law}$ is another source to enforce the rights of women workers. ${ }^{46}$ Tianjin evidently did not find this law to be adequate or effective and enacted another mechanism to encourage equality between the sexes.

The Chinese government holds the same attitude with the international human rights standards. Despite public statements declaring compliance with the various documents to which it is a party, "Chinese officials accept only in theory the universality of human rights. They argue instead that a nation's political, economic, and social system and its unique historical, religious, and cultural background determine its concept of human rights."47

Unfortunately, gender discrimination persists despite current laws, and a method to effectively address the problem needs to be implemented. Regardless of the laws and provisions discussed above, a report by Amnesty International states that "[t]hese human rights abuses in China are directly linked to grossly inadequate fundamental legal safeguards. The judicial system fails to ensure due process and adherence to basic international standards designed to protect individuals against abuse." ${ }^{\text {"8 }}$ The following

43. Id. See also Tianjin Formulates Local Regulations to Protect Women's Rights, supra note 41.

44. China Human Rights Practices, 1993 DEP'T OF ST. DISPATCH (U.S. DEP'T OF ST.), Feb. 1994.

45. ChINA Const., supra note 24 , art. 48.

46. Law Protecting Women's Rights and Interests, supra note 32.

47. China Human Rights Practices, 1994 DEP' T OF ST. DisPatch (U.S. DEP'T OF ST.), at sec. 4, Mar. 1995.

48. Prepared Testimony of Louisa Coan Board of Directors, China Country Coordinator, Amnesty International USA before the Committee on Intemational Relations Subcommittee on International Operations and Human Rights, FEDERAL NEWS SERVICE, July 18, 1995, available in LEXIS, ASIAPC Library, FEDNWS File thereinafter Prepared Testimony of Louisa Coan]. "In practice, China's legal reform efforts have not yet had a significant effect on protecting the rights granted to citizens in China's constitution and criminal and administrative procedure laws." Human Rights and Democracy in Asia, DEP'T 
factors, dealing with the bases of Chinese society and the nature of the market economy, all contribute to the inferior status of women in China despite the strong laws granting them equality.

\section{The Basis of Discrimination Against Women In ChIna}

\section{A. Historical and Cultural Basis of Discrimination}

China has a long history of stratification of the sexes in all areas of life. Women were traditionally bought and sold as wives or slaves. The purpose of a woman was to please the whims and fancies of her male superiors and to bear and care for the children, preferably male. This way of life was taught to men and women through the predominate teachings of Confucius. $^{49}$ He taught that every person had a place in society, that the place of a woman was subordinate to that of a man, and that "it is a virtue if a woman has no ability." ${ }^{50}$ Because of these beliefs, women in China have long been viewed and treated as greatly inferior.

The communist party, under Mao Zedong, believed that rooting out individualism would benefit the well-being of society as a whole. ${ }^{51}$ As a result, the communist party attempted to eliminate gender-based discrimination by minimizing the differences between the sexes by such acts as outlawing make-up, requiring uniforms, and implementing and enforcing strict employment quotas. ${ }^{52}$ Mao was fairly successful in achieving this goal, but only at the expense of the personal freedoms and liberties of all of the Chinese people. ${ }^{33}$

Unfortunately, as a result of the Chinese government's loosening its traditional control over society in favor of developing personal freedoms and a market economy, many of the prejudices against women have re-emerged. Practices such as the selling of wives, female infanticide and feticide, and prostitution have all increased since Mao's rule, ${ }^{54}$ so that "[a]s Chinese society focuses more on profit and as Communist morality loses its influence, women in some cases are losing the ground they gained in the Maoist years." 55 Confucian teachings, promoting the separation of classes and sexes, are now more frequently acted upon by companies and employers.

OF ST. DiSPaTCH (U.S. DEP'T OF ST.), Apr. 3, 1995.

49. Margret Y.K. Woo, Biology and Equality: Challenge for Feminism in the Socialist and the Liberal State, 42 EMORY L. J. 143, 177-80 (1993).

50. Karen Korabik, Managerial Women in the People's Republic of China; Competitive Frontiers: Asian Women in Management, 23 INT'L. STUD. OF MGMT. \& ORGANIZATION 47 (1993).

51. HsIUNG, supra note 1.

52. WuDunn, supra note 40.

53. Id.

54. Id.

55. Id. 


\section{B. Pervasiveness of Discrimination Against Women in China}

Not only does discrimination against women in China have a long history, but it also has spread into most areas of women's lives. Discrimination is reemerging in many aspects of the economy, including labor standards. ${ }^{56}$ Along with that, the sale of women is rising, prostitution rates are increasing, ${ }^{57}$ female feticide continues, ${ }^{58}$ and abuse within the home is still prevalent. ${ }^{59}$ In short, "[m]any Chinese women accept being beaten by their husbands and don't see that it's wrong." 60 The attitude of superiority held by men and the acceptance of subservience and abuse by women can be blamed as the main sources of society's employment discrimination against women. The discrimination is then carried from the home into other facets of life and society, including the job market. Because the prejudice is learned at the home, it becomes ingrained and extremely difficult to fight outside of the home. ${ }^{61}$

The government is attempting to address discrimination in the home, which should result in a reduction in labor market discrimination as well. A study published in March of 1994 on marriage and the family found "onefifth of all wives had been abused by their spouses."62 Recently, new guidelines have been enacted instructing Chinese police officers on how to handle a domestic violence call. ${ }^{63}$ Domestic violence is rarely reported in China, but when it is, the police usually view it as a family matter and do not interfere. ${ }^{64}$ The new guidelines focus on protecting the victim and any other family members who may be at risk. ${ }^{65}$ The guidelines also encour-

56. Makabenta, supra note 2.

57. WuDunn, supra note 40. "In 1991 and 1992, police investigated 50,000 cases of women being sold." Clouds Gather Over Chinese Women's half of the sky,' AGENCE FRANCE PRESSE, Aug. 29, 1993, available in LEXIS, ASIAPC Library, AFP File. But see China Human Rights Practices, 1994, supra note 47 (pointing out that in December of 1994, a gang of 48 people were sentenced to prison terms ranging from 19 years to life for abducting, raping, and selling women, showing the government taking action against such atrocities).

58. China Human Rights Practices, 1994, supra note 47; see also China Human Rights Practices, 1993, supra note 44.

59. Violations against women's rights also extend to the prisons, including forced abortion and forced sterilization. Prepared Testimony of Louisa Coan, supra note 48.

60. Breaking the Silence: China's Women Say No to Abuse by Men, THE STRAITS TIMEs, Aug. 16, 1994, at 11.

61. Asia-Women: Discrimination Begins at Home, says economist, INTER PRESs SERVICE, Apr. 25, 1994, available in LEXIS, ASIAPC Library, INPRES File. "Much of the deprivation of women arises not from discrimination in the marketplace but from disparity in intra-household allocation between sexes." Id.

62. China Human Rights Practices, 1994, supra note 47, sec. 5.

63. Ruth Mathewson, New Rules to Handle Home Violence; Police Set Code to Deal with Abuse, S. CHINA MoRnING POST, May 1, 1994, at 1.

64. Id.

65. Id. 
age stronger action, ranging from taking the victim to a safe refuge to serving one of the new domestic violence incident notices on the offender. ${ }^{66}$ This will result in more incidents being recorded and acted upon, which may raise awareness and allow women to better protect themselves. The regulations also make injunction orders easier to attain against an abusive partner. ${ }^{67}$ The enforcement of anti-discrimination laws in the domestic realm may lead to more strict enforcement of anti-discrimination policies in other areas, such as the work place, and may help educate women about the rights they do have.

Women in China are subject to greater health risks simply by being born women. ${ }^{68}$ Sex-based selective abortions and female infanticide still exist, especially with the government's one-child family policy and the strong cultural preference for male children. ${ }^{69}$ Female children are often denied the family's scarce resources when it comes to education, food, and medicine. ${ }^{70}$ As a result of the lack of educational opportunities available to women, seventy percent of the illiterate in China are women. ${ }^{71}$ All of these factors contribute to the lowly status and lack of well being for women, affecting their standing in other areas of life, including work. ${ }^{72}$ Even when the same criteria is used to evaluate female and male applicants for a position, women do not have the same access as men to attain or develop these skills. ${ }^{73}$

\section{The Influence of the Market Economy on Women's Status}

The surge of the market economy in a society ingrained with cultural traditions is frequently described as a mixed blessing for the Chinese women even though "[m]ore than a decade of rapid economic growth has raised living standards and enabled growing numbers of Chinese to assume greater control over their own lives. The scope for private economic activity has expanded rapidly, and the degree of government and party control over the economy has continued to decline." ${ }^{.74}$ The market reforms have created many new options for women, with the greatest opportunity lying in self-

66. Id.

67. Id.

68. Carolyn Adolph, Sex Discrimination Deadly, Report Says, OtTAWA CrtIzEN, Sept. 27,1994 , at $\mathrm{A3}$.

69. Korabik, supra note 50; see also China Human Rights Practices, 1994, supra note 47 (revealing that ultrasound is sometimes used for this purpose in direct violation of the Maternal and Child Health Law which was passed in October).

70. Adolph, supra note 68.

71. WuDunn, supra note 40; see also Ruth Youngblood, China's Economic Boom Leaves Women Behind, UPI, Oct. 10, 1994, available in LEXIS, ASIAPC Library, UPI File.

72. Adolph, supra note 68. See China Human Rights Practices, 1993, supra note 44.

73. Korabik, supra note 50.

74. China Human Rights Practices, 1994, supra note 47, sec. 1. 
employment. ${ }^{75}$ But the increased competition has forced private businesses and companies to make more efficient use of their labor resources, resulting in a greater amount of discrimination against women in the labor market. ${ }^{76}$ As a result of the new reforms, women are the last to be hired and the first to be laid off, under the guise of a variety of excuses, ${ }^{7}$ and this is reflected in the startling statistic that "[w]omen make up seventy percent of the twenty million workers made idle by the enterprise reform."78 There are three major battles facing women in the market place: 1) against unemployment and job access; 2) against unequal payment for work done; and 3) against the historic social structure and family responsibilities still imputed to women only. ${ }^{79}$

\section{Female Unemployment and Job Access}

A main factor for the increasing employment distinctions between men and women is that Chinese citizens are now more mobile. Men are more free to move from their homes to where the jobs are located. When this mobility was restricted, the jobs would go to the women in the region, due to the lack of other applicants: ${ }^{80}$ "Faced with the large pool of applicants comprised of entrants, displaced workers and migrants from rural areas, employers can also more easily exercise biases against hiring women that are unrelated to costs." 81

There are several rationalizations or excuses given by companies as to why they prefer male employees over female employees, reflected in the protective provisions in the 1988 Rules. $^{82}$ First, women are believed to be less versatile than men because they are less capable of heavy manual labor. ${ }^{83}$ Second, mandatory maternity leave and child care provisions

75. Gale Summerfield, Effects of the Changing Employment Situation on Urban Chinese Women, 52 REV. OF SOC. ECON. 1, part IV (1994).

76. Id.

77. Woo, supra note 49, at 144. See HiLARY K. JOSEPHS, LABOR LAW IN CHINA: CHOICE AND RESPONSIBILITY 50-51 (1990).

78. Breaking the Silence: China's Women Say No to Abuse by Men, supra note 60. See also Korabik, supra note 50 (discussing the fact that because of China's massive population, there is a large surplus of labor, of which women constitute 64 percent); Clouds Gather Over Chinese Women's 'half of the sky,' supra note 57 (noting that women make up two-thirds of the urban Chinese who are unemployed).

79. Woo, supra note 49 , at 175.

80. Sumerfield, supra note 75.

81. Id. at 45. Not all of the new migration into the cities is legal, but the government is no longer actively opposing the illegal migration. Id. See China Human Rights Practices, 1993, supra note 44. See also Women Account for 70 percent of China Farm Labor, REUTERS LIMITED, Mar. 9, 1994, available in LEXIS, ASIAPC, TXPRIM (rural women in China earn an average 22 percent less than men and have lower rates of mobility).

82. See supra part II.B.

83. JOSEPHS, supra note 77; see also Summerfield, supra note 75. 
impose extra costs on the company. ${ }^{84}$ Finally, women are considered less efficient because of child care and household duties which they also have to undertake. ${ }^{85}$ More than two-thirds of the work units prefer men to women. $^{86}$ Therefore, even of the women graduated from college, eighty to ninety percent have difficulty securing a job. ${ }^{87}$ In this way the protective measures imposed by the laws work as a double edged sword. They prevent employers from mistreating women during pregnancy, but they also cause employers to see women as less desirable than men because of the possibility of an extra burden. ${ }^{88}$

\section{Unequal Remuneration}

Businesses are able to circumvent the "equal pay for equal work" provisions by limiting women to certain types of employment, ${ }^{89}$ so that the equal work requirement, which would require equal pay, does not arise. Women do not do the same work that men do. This practice often results in what is termed a "gender ghetto." Lower standards and lower minimum wages develop which prevail across the market and are therefore not actionable, nor recognized, as discriminatory. ${ }^{90}$

Related to the "gender ghetto" is the glass ceiling that women in China face, similar to that encountered by women in many other countries. The women who are gainfully employed are concentrated in entry level positions." "Male managers still far outnumber the female managers in China . . the higher the post, the fewer the women."92 The areas where women managers exist are the traditionally female industries. This is due to the belief that it is acceptable for women to have positions of authority, as long as they do not have authority over men. ${ }^{93}$

84. China Human Rights Practices, 1994, supra note 47; see also JOSEPHS, supra note 77; see also Summerfield, supra note 75.

85. JOSEPHS, supra note 77; see also Summerfield, supra note 75.

86. Karen Korabik, Women Managers in the People's Republic of China: Changing Roles in Changing Times, 42 APPLIED PSYCHOLOGY: AN INT'L. REV. 353, 358 (1993).

87. Id.

88. Korabik, supra note 50.

89. Traditionally women are limited to female industries, low-skilled jobs, or production-operation positions.

90. Travis, supra note 22, at 176; see also China Human Rights Practices, 1994, supra note 47. See also Noeleen Heyzer \& Vivienne Wee, Obstacles to Women's Advancement, BUS. TMMES, Apr. 30, 1994 (the gender-ghetto effect is pervasive throughout the region); see also Korabik, supra note 50 ("Despite the equal pay laws, Chinese women earn only about 72 to 74 percent of what men earn."); see also Maria Hsia Chang, Women, in HuMAN RIGHTS IN THE PEOPLE'S REPUBLIC OF CHINA 251, 263 (1988); see also Youngblood, supra note 71 (reporting ratio of income for urban women to urban men as 77:100).

91. Korabik, supra note 50.

92. Id.

93. Id. 


\section{Social Structure and Family Responsibilities}

Employees in China can be disciplined for immoral behavior. This is often used as a means to discipline or dismiss women who fail to conform to family planning rules. ${ }^{94}$ Women who are on a maternity leave, or planning to take a maternity leave, are often illegally dismissed under false pretenses. ${ }^{95}$

Some people have taken these biases even further toward excluding women from the work force.

The change away from guaranteeing employment is a big step for socialist ideology.... A dramatic reversal in attitudes toward women has emerged in praise for the housewife. This has ranged from emphasizing the spiritual role of women in guiding the family to concern for the double burden women face. The proposed way to deal with the double burden is not to socialize domestic chores but to remove women from the labor force. ${ }^{96}$

Even though this is a completely unrealistic view, the existence of this mentality perpetuates and encourages the needless ungrounded discrimination against women in the work place.

One excuse presented for the stratification between women and men is the actual physical/biological differences, based on a woman's power of reproduction. "The latest reality in China is that women's problems are no longer discussed as social problems but rather as a matter of biology."97 This is evident in the Law Protecting Women's Rights and Interests, the Rules on Labor Protection of Female Workers, and the new Tianjin law. ${ }^{98}$ China's laws include extensive provisions and prohibitions for women because of strength, menopause, menstruation, pregnancy, nursing, and maternity leave. Although most of these provisions serve a positive purpose, they occasionally go too far. ${ }^{99}$ Companies frequently require women to retire at age sixty, while men may retire at age sixty-five, because of menopause and the duty to take care of the family household. ${ }^{100}$ Some employers have even lowered the retirement age for women to forty years

94. JOSEPHS, supra note 77; see also STATE DEPARTMENT's HUMAN RIGHTS REPORT: HEARING OF THE INTERNATIONAL SECURITY, INTERNATIONAL ORGANIZATIONS, AND HUMAN Rights SubCOMMITTEe OF THE HOUSE OF FOREIGN AFFaIRS COMMTTEE, (Feb. 1, 1994) (statement of Timothy Wirth, Assistant Secretary of State).

95. Id.

96. Summerfield, supra note 75 , at 36 .

97. Woo, supra note 49 , at 145.

98. See supra part III.B-D.

99. Woo, supra note 49. See also supra part III.B. (climate condition restrictions during menstruation).

100. Korabik, supra note 50. 
of age. ${ }^{101}$ Women's early retirement age is a burden on employers when hiring women instead of men who could work until age sixty-five. ${ }^{102}$ It also limits women's opportunity for career advancements once hired. ${ }^{103}$

The combination of the difficulty for women to find employment, receive equal treatment once employed, and assume the traditional responsibilities of their gender, makes for a difficult climb for Chinese women. Without active participation of the government in improving the status of women throughout society, Chinese women have a nearly impossible task ahead of them to earn respect and equality in an oppressive market place. The traditional prejudices against women in the booming market economy are being increasingly asserted, contrary to the mandates of the international community and China's own laws.

\section{China's Political Position and Human Rights Status}

\section{A. China's Current Political Forces}

In order to appreciate the sensitive subject of China's human rights practices, and the United State's involvement in China, an understanding of the complex dual system created in China is essential. The former U.S. ambassador to China, James Lilley, described China's current and unique economic and political system:

They say they (China) have to have political authoritarianism and a socialist market economy . . . . It has lead to a rapid and sustained economic growth. It has led to fundamental changes in economic structure. It has led to rapidly growing market infrastructure. And it has introduced genuine competition into its economy. ${ }^{104}$

Also included in this mix are modern societal problems of personal corruption, inflation, and income disparity. ${ }^{105}$ All of these factors contribute to the increased population migrations, unemployment, and discrimination. ${ }^{100}$

Culturally, the Chinese are accustomed to a legal system based on the rule of a person, or party, effected through laws. This is directly contrary to the U.S system which is based on rule of law, as enforced by people. ${ }^{107}$

101. China Human Rights Practices, 1994, supra note 47.

102. Korabik, supra note 50.

103. Id.

104. Lilley, supra note 3.

105. Id.

106. $I d$.

107. Id. 
China's historical dependence on governance by personality could be a contribution to the ineffectiveness of the existing laws.

Because of the Chinese government's tight control over society, information is not frequently released about the status of any particular class in China, and foreigners are unable to conduct independent research. "There are no independent Chinese organizations that publicly monitor or comment on human rights conditions in China. The Government has made it clear it will not tolerate the existence of such groups." 108 Because of this practice, statistics and data are scarce. China's attempt at addressing its human rights practices are the recently published White Papers. ${ }^{109}$ The papers enthusiastically defend Chinese practices, while glossing over important problems. ${ }^{110}$

For example, it is reported that seventy percent of women over the age of fifteen are in the labor force, which is a relatively high and respectable number. ${ }^{111}$ However, the percentage is also misleading because of the business practices described above which are used to keep women's status inferior in the labor market. ${ }^{112}$ The number of women employed is not necessarily indicative of equality and fair treatment of both sexes. Unfortunately, accurate data is unavailable. Another attempt by China to address women's issues is an organization called the All China Women's Federation. ${ }^{113}$ This organization is beneficial to Chinese women, but only to a limited extent because it exists under the control of the state. ${ }^{114}$

As indicated previously, China has several laws intended to eliminate discrimination against women, but what is written in China does not always reflect what is practiced. "The exercise of [women's] 'constitutional rights' is entirely contingent on the parties determination as to women's 'real' needs and interests." 115 This is evident in the protective measures limiting women's activities for various reasons. Most disturbing is the sudden increase in discriminatory practices due to the growth of the private market economy and foreign influence.

\section{B. The U.S. Perception of the Status of Chinese Women}

The perception by the United States Department of State of women in the Chinese work force is quite different from that presented by the Chinese government. The U.S. Department of State issued a report on China's 1993

108. China Human Rights Practices, 1994, supra note 47, 44.

109. See infra part V.C.

110. China Human Right's Practices, 1993, supra note 44.

111. Summerfield, supra note 75, at part VII. See supra part IV.C.

112. Id.

113. Woo, supra note 49, at 194.

114. Id.

115. Chang, supra note 90. 
human rights practices, addressing the discrimination against women in China's work force. ${ }^{116}$

In Fact, most women employed in industry work in lower skilled and lower paid jobs. Women hold relatively few positions of significant influence within the party or government structure. Persistent problems have remained with regard to the status of women, who have often been the unintended victims of reforms designed to streamline enterprises and give workers greater job mobility. ${ }^{17}$

These practices are not conducive for women to achieve the goal of total equality mandated by the Chinese Constitution and subsequent legislation. Overall, "China's human rights record in 1993 was the worst since the 1989 crackdown."118 The 1995 report from the Department of State, discussing 1994, showed no substantial improvement in the status of women in the Chinese work force. The report attributed much of women's strife to economic reform. ${ }^{119}$ Reports continuously reach the United States about labor violations against women workers in China. These reports are usually in the form of individual stories or incidents, because of the difficulty of conducting any type of comprehensive investigation in China. Even without access to the daily practices of the Chinese, the widely published events and conditions surrounding the United Nations Fourth World Conference for Women clearly portrayed the Chinese government's attitudes concerning women. China fought and won the right to have the September 1995 conference in Bejing. But once the event arrived, the government was incredibly uncooperative, greatly harming its image in the eyes of the world by attempting to hinder the productivity of the women gathered in the name of human rights. ${ }^{120}$

\section{China's Representation of the Status of Women's Right's in China}

China's own interpretation of women's status within the country represents the problem as minimal, if existent at all. To confront the human rights issues within China, at the request of the international community, the government has begun to publish "White Papers" as a report on various

116. China Human Rights Practices, 1993, supra note 44.

117. $I d$.

118. Michel Moutot, Asia Watch Says China's Human Rights Record Worsening, AGENCE FRANCE PRESSE, Feb. 20, 1994, available in LEXIS, ASIAPC Library, AFP File.

119. China Human Right Practices, 1994, supra note 47.

120. The long term ramifications of the Chinese government's actions during the conference cannot yet be discerned. Such treatment of women gathered together for the purpose of advancing discussion and action in the direction of increased human rights for women around the world cannot bode well for the immediate future of women in China. 
human rights issues. ${ }^{121}$ A series of White Papers entitled "The Situation of Chinese Women" were published in June of 1994 and made the following representations (among others): that the status of Chinese women is not entirely satisfactory because of the influence of old concepts and the constraints of social development; ${ }^{122}$ that "[f]rom time to time" women experience instances of prejudice, discrimination, and infringement of their rights; ${ }^{123}$ that extensive legislation exists within the Constitution, the Law on the Protection of Rights and Interests of Women, and various specific state laws, regulations, and administrative measures, which are based on the equal rights of men and women, protection of special rights and interests of women, and elimination of discrimination; ${ }^{124}$ that the basic principle that women enjoy equal working rights with men is detailed; ${ }^{125}$ that enforcement of the granted rights is addressed by creating a committee to conduct surveys and make suggestions for resolution, empowering courts to judge cases of infringement on women's rights and interests, supporting women's organizations including the All-China Women's Federation, and supporting the media and other means furthering the female self-improvement campaigns. ${ }^{126}$

In these statements China does acknowledge that there is still some level of discrimination against women in China, but that everything possible is being done by the government to combat that discrimination. ${ }^{127}$ The cultural background of the people is the main source of the discrimination, but the prejudices are revealed more than "from time to time" as represented by the White Papers. ${ }^{128}$ The mere existence of legislation is insufficient to realize equality among men and women if the legislation is not actively enforced by the government and compliance mandated. Although some recourse is provided for women who are empowered enough to seek it, the government should take independent action to assure compliance to the laws

121. See Orentlicher \& Gelatt, supra note 5 , at 72 (proposing that the White Paper is questionable and biased).

122. China: White Paper; The Situation of Chinese Women, 1 of 10, BBC MonITORING SERVICE: FAR EAST, June 11, 1994, available in LEXIS, NEWS Library, TBBCSW File.

123. Id.

124. China: White Paper; The Situation of Chinese Women, 4 of 10, BBC MONITORING SERVICE: FAR EAST, June 11, 1994, available in LEXIS, NEWS Library, TBBCSW File.

125. China: White Paper; The Situation of Chinese Women, 9 of 10, BBC MONITORING SERVICE: FAR EAST, June 11, 1994, available in LEXIS, NEWS Library, TBBCSW File.

126. Id.

127. See David Schlesinger, China: China Keeps Tough Line on Rights before U.S. Visit, REUTER TEXTLINE, Aug. 27, 1994, available in LEXIS, ASIAPC Library, TXTLNE File (asserting that China is ahead of United States on human rights issues, including ending discrimination against women).

128. See supra note 122 and accompanying text; see also infra part IV.B. 
to protect those who are not able to protect themselves due to the vicious cycle of discrimination. Because the discrimination is increasing instead of decreasing, the international community should consider taking independent steps toward improving the human rights of the Chinese.

\section{THE INFLUENCE OF THE UNITED STATES AND FOREIGN JOINT VENTURES ON WOMEN'S RIGHTS IN CHINA}

\section{A. China Blames Foreign-Funded Joint Ventures for Women's Rights Violations}

Chinese organizations have suggested that foreign-funded businesses are not adequately looking after domestic employees' rights. ${ }^{129}$ A decree was issued in April 1994 as a result of pressure from the All-China Federation of Trade Unions (ACFTU), that "by the end of this year, trade unions must be set up in all foreign invested firms in economic development zones and coastal cities." ${ }^{130}$ Wide spread labor unrest is the reason for the new urgency for trade unions, and part of that unrest is in response to the recent surge in gender-based employment discrimination.

The ACFTU is targeting foreign joint ventures as leading contributors to the poor human rights record in the workplace, even though there are at least 8,200 trade unions set up in foreign invested ventures. ${ }^{131}$ It was reported from a survey of foreign funded enterprises in Guangdong Province that "the workers are mainly women and many of them complain of sexual harassment, long working hours, beatings and being forced to work on dangerous machinery or stand for many hours even when pregnant."132 The ACFTU reported that women working in foreign-owned enterprises experience some form of gender discrimination, such as unequal pay, mandatory overtime without pay, and dismissal for pregnancy or marriage. ${ }^{133}$ The claim is also made that maternity leave was not granted in nearly one-half of the foreign-funded firms investigated in recent

129. Zhang Xia, China: State Seeks Expanded Trade Union Role in JVs, ChINA DaIlY, June 29, 1994.

130. Id.

131. Id. See also China Human Rights Practices, 1994, supra note 47, \$6(a) ("The AllChina Federation of Trade Unions is controlled by the Communist Party. Independent trade unions are illegal.") - This suggests some inconsistency in the policy and traditional purpose of trade unions to speak for the people. See also China: Joint Ventures Must Set Up Trade Unions, supra note 4 (specifies greatest offenders as joint-ventures are Hong Kong, Taiwan, the Republic of Korea, and Japan).

132. Yojana Sharma, China-Labor: A Workers' Paradise Under Market Lenisim, INTER PRESS SERVICE, July 7, 1994 available in LEXIS, ASIAPC Library, INPRES File.

133. China's New Labor Law, Other Labor Initiatives: Are Female Workers' Organizations on Horizon?, E. ASIAN EXECUTIVE REP., June 15, 1994. 
years. ${ }^{134}$ A researcher for a Hong Kong based human rights group equates China's labor laws to administrative measures, and states that "many private entrepreneurs, and particularly foreign-funded enterprises think that the labor protection regulations do not apply to them."135

Workers' rights, including women's rights, were more closely monitored and protected by the government before the market reforms. ${ }^{136}$ Now that there is a large growth of private enterprises, the workers are vulnerable to exploitation. ${ }^{137}$ This concern prompted the National People's Congress to pass a long awaited labor law which came into effect January 1,1995 , and includes benefits and protections for women workers, including maternity leave. ${ }^{138}$ But this new labor law also includes protective provisions which will not allow women to work under hardship conditions, ${ }^{139}$ perpetuating the concept that women employees are less versatile and therefore less valuable. Although China does not like interference from foreign sources, foreign companies are the main violators of the human rights laws, then international solutions need to be addressed and embraced by China.

\section{B. Foreign Interference in China's Domestic Realm}

The standard source for any grant of citizens' human rights is the Constitution. In Article 48 of China's constitution, women are explicitly granted equal rights with men in the economic sphere of life as well as in all other areas. ${ }^{140}$ Chinese women have been granted equal rights by their constitution, but the enforcement of those granted rights remains problematic. China reiterates the importance of the provision of Article 48 in the Rules on the Labor Protection of Female Workers. ${ }^{141}$ This demonstrates that China has attempted to make improvements in the

134. China Union Calls for Improvements for Female Workers, AGENCE FRANCE PRESSE, Jan 8, 1994, available in LEXIS, ASIAPC Library, AFP File.

135. Sharma, supra note 132.

136. Id.

137. Id.

138. Id.

139. China's New Labor Law, Other Labor Initiatives: Are Female Workers' Organizations on Horizon?, supra note 133. The new law also sets out provisions for employment, labor contracts, working hours, wages, skill development and training, social insurance, dispute resolution, legal responsibility, supervision, and inspection. China Human Rights Practices, 1994, supra note 47, \$4(e). See also Douglas C. Markel, Finally, a National Labor Law; Labor Law of the People's Republic of China, 21 CHINA BUS. REV. 6, Nov. 1994, at 46 . (The new law still does not provide specific enforcement measures to ensure its goals. Nine new laws are currently underway to lend force to the new Labor Law. Id.)

140. ChINA Const., supra note 24, art. 48 (even includes provision requiring "equal pay for equal work for men and women alike").

141. See supra part III.C. 
enforcement of women's rights in the economic sphere, but international efforts may now be needed to assist in the realization of these rights.

Whether the United States is in a position to assist with any type of program is debatable: "Sex discrimination is a human rights issue that can be addressed by national legal systems far more effectively than by international mechanisms." ${ }^{142}$ Even when there are explicit laws against discrimination, the laws may not be effective in alleviating the problem for various reasons described above. ${ }^{143}$ International efforts to prevent the breach of human rights can serve as a final resort when the national attempt is ineffective. The international efforts also serve to establish global standards and to educate the government and citizens. ${ }^{144}$

China is in a peculiar position to be effectively influenced by outside forces because of its heavy reliance on the international market. In a presentation given on May 31, 1994, the former U.S. ambassador to China, James Lilley, pointed out that China is the largest borrower in the world from the World Bank. ${ }^{145}$ The United States was the second largest foreign investor in China in 1993, involved in almost all areas of its market and development. ${ }^{146}$ This involvement allows for the possibility of greater influence over Chinese policies. Action by the United States may also inspire others to follow and join in the fight for encouraging equal employment practices for men and women alike.

\section{Specific Action by the United States}

Human Rights issues have been the cornerstone for American-Chinese relations since it was laid out as such by James Baker in $1990 .{ }^{147}$ In section 142 of Public Law 236 of the 103rd Congress, enacted on April 30, 1994, the United States recognized that the "issues of gender-based discrimination and violence against women have long been ignored or made invisible." 148 This statement reaffirmed the U.S. commitment to these issues and their importance within the international human rights policy of the government.

By placing various human rights restrictions on trade and investment, the United States does have the power to influence gender-based employment discrimination due to the new dependence of the Chinese on a world market economy. Women's organizations and the ACFTU have pointed to foreign invested joint ventures as perpetuating the poor human

142. Marsha A. Freeman, Women, Law, and Land at the Local Level: Claiming Women's Human Rights in Domestic Legal System, 16 HUM. RTS. Q. 559, 563 (1994).

143. See supra part IV.C.

144. Freeman, supra note 142.

145. Lilley, supra note 3.

146. Orentlicher \& Gelatt, supra note 5 at 68.

147. Lilley, supra note 3.

148. Pub. L. No. 103-236, $\S 142,108$ Stat. 382 (1994). 
rights standards in the labor market. ${ }^{149}$ The United States displayed its commitment to fighting gender discrimination by declaring at the World Conference on Human Rights that "the elimination of abuses and discrimination against women will be an important factor in our overall consideration of the human rights records of countries interested in receiving U.S. aid and trade benefits."150 As a world leader, it is especially important that the United States takes visible and strong actions to combat discriminatory labor practices in order to encourage other foreign investors, and the Chinese themselves, to follow.

The Chinese condemn such actions as intrusions on their soverignty by foreigners. They assert that human rights issues are internal matters, and external intervention or criticism interferes with China's internal affairs and sovereignty. ${ }^{151}$ The argument is that for one country to use the issue of human rights to effectuate an end result in another country is manipulative and endangers world peace and security. ${ }^{152}$

Even with the implementation of U.S. trade linked to human rights standards, there is no guarantee that it would be effective: "In short, genderbased, discriminatory working conditions and a panoply of other issues of critical concern to women workers remain stubbornly outside the grasp of worker rights provisions in U.S. trade statutes." 153 The success in reducing the recent surge in gender-based employment discrimination through a U.S. provision depends on several factors as discussed above. There are various means by which the United States, or its companies, may attempt to assert its influence over China, and the two most likely mechanisms are Most Favored Nation status (MFN) and the Miller Principles.

\section{China's Most Favored Nation Status}

In 1994, President Clinton again granted an extension of China's Most Favored Nation status, including a list of conditions which China's government must meet in order to continue to receive nondiscriminatory MFN treatment. ${ }^{154}$ One prerequisite is that China must be "taking steps to begin adhering to the Universal Declaration of Human Rights." fundamental and universal human right included by this clause is freedom from gender-based employment discrimination. Because gender-based discrimination in the work force can be a factor in the determination of

149. See supra part VI.A.

150. Violations of Women's Human Rights, supra note 8.

151. China Human Rights Practices, 1993, supra note 44.

152. Chinese Official on Human Rights, XINHUA NEwS AGENCY, Dec. 28, 1993, available in LEXIS, ASIAPC Library, XINHUA File.

153. Travis, supra note 22, at 176.

154. Pub. L. No. 103-236, $\$ 513(a)(3)(A), 108$ Stat. 382 (1994).

155. Id. See Orentlicher \& Gelatt, supra note 5, at 79. 
China's MFN status, the United States can use this as a tool to encourage China to prevent and punish discriminatory practices.

Granting MFN status places the lowest possible tariffs on China's exports to the United States. ${ }^{156}$ Because of this, the grant or withdrawal of the MFN status is of foremost concern to China, as well as to many American companies who deal extensively with China. Some statistics show the United States as China's largest overseas market. ${ }^{157}$ American companies, especially those involved in joint ventures, rely on China retaining its MFN status for their own advantage. ${ }^{158}$ China's dependence on MFN status should assure the United States that the grant can be used as an incredibly powerful tool to force China's hand on the issue of human rights, but it remains a tool that must be used carefully, as revoking MFN would devastate many innocent people who may not be the ones the United States is attempting to reach with the punishment. ${ }^{159}$

\section{The Miller Principles}

Another possible means to effectuate a change in the treatment of Chinese women is through a proposal called the Miller Principles, which as introduced to the U.S. Congress would codify workers rights provisions for U.S. companies working in China. ${ }^{160}$ It was developed by U.S. Representative John Miller, and first introduced to Congress in March 1991, but has not yet been accepted by the legislature. The principles are "aimed at encouraging political freedom and liberalization within the People's Republic of China and Tibet."161

The Miller Principles were inspired by The Sullivan Principles, implemented to combat racism and end apartheid in South Africa. ${ }^{162}$ The Sullivan Principles were originally adopted by companies on a voluntary basis, like the Miller Principles are today. ${ }^{163}$ Eventually, an executive order was issued by President Reagan forbidding U.S. export assistance to U.S. companies who had not adopted the Sullivan Principles. ${ }^{164}$ The

156. Id.

157. Id.

158. Id. at 76. Conitinuation of China's MFN status benefits American companies as it then costs less to import already cheap Chinese goods; such companies also fear that China will retaliate against American products in favor of foreign competitors if MFN is withdrawn. Id. at 79-81.

159. Lilley, supra note 3.

160. Jorge F. Perez-Lopez, Promoting International Respect for Workers Rights through Business Codes of Conduct, 17 FoRDHAM INT'L. L.J. 16 (1993).

161. Id.

162. Orentlicher \& Gelatt, supra note 5, at 45; see also Perez-Lopez, supra note 160 , at $22-30$.

163. Id.

164. Id. 
principles were then incorporated into the Anti-Apartheid Act of 1986. ${ }^{165}$ The Sullivan principles may not have brought an end to apartheid, but they are recognized as a valuable contribution. ${ }^{166}$ The Miller Principles could make a similar contribution to the improvement of China's human rights practices in the work place, including gender based discrimination.

The Miller Principles set forth a list of human rights guidelines for American companies who are participating in business ventures or other projects in China. ${ }^{167}$ It only applies to those companies which employ more than twenty-five people, or have assets greater than $\$ 25,000 .^{168}$ One of the principles addressing discrimination in the labor force provides that companies should "[s]eek to ensure that ... sex ... will not prohibit hiring, lead to harassment, demotion, or dismissal, or in any way affect the status or terms of employment in the industrial cooperation project." ${ }^{169} \mathrm{Al}$ though not yet adopted by the legislature when President Clinton renewed China's MFN status for 1994, he endorsed the Miller Principles as a set of voluntary principles for American firms operating in China. ${ }^{170}$ Many companies have independently adopted a company code of conduct based on the Miller Principles to apply to their international activities in China. ${ }^{171}$

Some worry that implementing a code would on balance hurt U.S. businesses and corporations. A public affairs executive for AT\&T China Inc. believes that "a code of Conduct would be viewed by the Chinese government as another attempt to influence Chinese domestic politics and would be detrimental to U.S. business." ${ }^{172}$ The argument is also made that it is not the role or place of the business community to exert influence on another country's human rights issues. Even if businesses do not have a responsibility to concern themselves with another countries human right practices, businesses do have a market interest in human rights because of the increasing awareness of consumers about a company's internal business practices. Companies also have an interest in assuring their investment is sound, in a stable market and culture. ${ }^{173}$

The adoption of the Miller Principles by Congress would demonstrate the commitment of the United States to equality in the work force in China, but it would only directly effect a very limited number of Chinese

165. Id.

166. Steven Mufson. For U.S. Firms in China, a Struggle Over Rights and Roles, WASH. Post, Aug. 25, 1994, at B 10.

167. Perez-Lopez, supra note 160.

168. Id.

169. Id.

170. Mufson, supra at 166.

171. See infra part VI.C.3.

172. Mufson, supra note 166.

173. Orentlicher \& Gelatt, supra note 5, at 95-97. 
workers. ${ }^{174}$ The Miller Principles are only required to be adhered to by the best efforts of the company, retaining a great deal of autonomy for the companies. Another limiting factor is that they would only affect Chinese workers employed by American companies in China. Despite these limitations, "businesses that may or do invest in China bear a responsibility to ensure that their actions do not, however inadvertently, contribute to the systematic denial of human rights in the PRC."175 The implementation of the Miller Principles would still be valuable to Chinese workers in decreasing gender-based employment discrimination by providing a role model for Chinese companies as well as for other foreign investors in China. ${ }^{176}$

\section{Independent Actions Taken by American Companies in the Condemnation of China's Human Rights Violations}

Some companies in the United States are now taking steps to insure that their international branches or suppliers are free from human rights violations. Specifically, Sears, Roebuck and Co. declared in January of 1993 that it would no longer import forced-labor products from China. ${ }^{177}$ Phillips-Van Heusen, likewise, has threatened to cancel orders from companies that violate its broad human-rights code. ${ }^{178}$ Reebok International Ltd. adopted a human rights code of conduct in 1992 for all of its overseas operations, including China, which governs work place conditions. ${ }^{179}$ Similarly, Timberland Company ended its sourcing from China in February of 1993 because of pervasive human rights violations, ${ }^{180}$ and Levi Strauss \& Co. shortly followed suit. ${ }^{181}$

American companies are beginning to take individual responsibility to insure their products are not encouraging or perpetuating human rights violations, which include gender-based employment discrimination. Along with American companies acting on their own accord, Beijing was denied the 2000 Olympics because of its marred human rights record. ${ }^{182}$ These actions should send a strong message to China that the international

174. Perez-Lopez, supra note 160 , at 43.

175. Orentlicher \& Gelatt, supra note 5, at 68.

176. See also Mufson, supra note 166 (discussing whether business should be involved with human rights issues and U.S. role of moralizing for others).

177. John McCormick \& Marc Levinson, The Supply Police, NEwSWEEK, Feb. 15, 1993. at 48. See Orlentlicher \& Gelatt, supra note 5, at 67.

178. Orentlicher \& Gelatt, supra note 5, at 67.

179. Id. at .106-08.

180. Id.

181. Id.

182. William Drozdiak, Sidney Tops Beijing for Olympics; China Loses Bid for Games in 2000 by Two-Vote Margin, WASH. POST, Sept. 24, 1993, at A1. (Although the vote was very close), (45 to 43 for Sydney) human rights violations was the primary or only reason for the loss.) 
community is taking these violations against Chinese people seriously and will continue to fight for equality in China, even if it is against the will of the government.

\section{CONCLUSION}

Now that China is rapidly expanding its market economy, discrimination against women appears to be increasing, and this trend must be quickly confined and reversed. The most effective method of eliminating discrimination would be by attacking its roots, through the education of men and women about human worth and the value of gender equality: "A higher level of education is needed in order for women to be in a position to take advantage of the new economic opportunities."183 Providing women with equality in the work force is a crucial step in developing a sense of equality and confidence in all areas of life, as more and more Chinese women come to accept the necessity of gainful employment in a person's overall wellbeing. Education is essential to participating successfully in the market, as well as in the rest of society. ${ }^{184}$ The education and personal successes of individual women will contribute to the elimination of prejudices in the deeper levels of the society. Although laws and regulations may purport to help those with the heavy burden of discrimination, they do not change the prejudice; that can only come by the educational advancement of the society, and women repeatedly proving themselves as truly equal in all aspects of life.

Even if there were massive educational campaigns, they would need to be supplemented for a more immediate result. Women deserve equality now, and beliefs which are ingrained into a society cannot be reversed overnight; therefore, the Chinese government needs to actively seek and ensure equality for women. The Chinese government could begin by enforcing the provisions already in existence in the Constitution and the Laws Protecting Women's Rights and Interests, by investigating and monitoring companies for violations, and implementing fines or other penalties. Although these provisions may not change the prejudices so deeply held by people, at least women would receive equal opportunities and treatment, allowing the educational process to continue.

In the absence of an aggressive effort by the Chinese government to eliminate the discriminatory treatment against women in the work force, actions by international forces would be the next step. The world as a whole made a strong statement against China's failure to enforce the human rights of its citizens by denying China the 2000 Olympics because of these same violations. The international community has an interest in ensuring equality and human rights within China because of China's active participa-

183. Korabik, supra note 86.

184. LANGLEY, supra note 12 , at $\mathrm{xv}$. 
tion in the enlarged international market. Because China's economy does rely on the international market, organizations such as the ILO and the U.N. could use their authority to demand China to act in accordance with their own domestic laws to combat flagrant gender inequality.

The United States particularly has the necessary influence over China to encourage China's compliance with the international communities' standards regarding women's rights. The United States cannot force China to take action against violators. However, extensive pressure can be applied through economic restrictions, such as the withdrawal of China's MFN status or enactment of the Miller Principles, to make it beneficial for China to take action. As the Sullivan Principles had an effect in South Africa, so could the Miller Principle substantially affect China, without encroaching on the Chinese governments sovereignty and domestic authority. Some American companies have adopted the theory of self-regulation behind the Miller Principles into their own policies. Taking independent measures to ensure an absence of human rights violations within their business dealings with China, these companies display concern for the injustice and leadership in the business community while improving the lives of those Chinese they deal with.

The international community is serious about the need of improvements in China's human rights. Measures encouraging the need for elimination of gender-based discrimination by the United States would not only notify China of the international concern, but would serve as a model for other countries investing in China to follow. The United States, and American companies, need to not only check their own practices, but ensure that the Chinese businesses with which they deal have more than antidiscrimination policies, but also actively practice employee equality and discourage gender-based discrimination. These pressures exerted by the United States, and American companies, should be continued and intensified until it is clear that China's government is taking active and effective measures to ensure the elimination of discrimination against women in the work force, as well as in all areas of life.

Allison J. Wells 
